\title{
On the taxonomic status of Ochromolopis ictella (Hübner, 1813) and $O$. zagulajevi Budashkin \& Sachkov, 1991 (Lepidoptera, Epermeniidae)
}

\author{
REINHARD GAEDIKE ${ }^{1}$, RichaRd MALLY ${ }^{2}$ \\ 1 Florusstraße 5, 53225 Bonn, Germany; tinagma@msn.com \\ 2 University Museum of Bergen, Natural History Collections, Allégaten 41, 5007 Bergen, Norway; \\ richard.mally@um.uib.no
}

http://zoobank.org/D518C8D6-3E65-437E-AA4A-E9212D34C085

Received 24 September 2013; accepted 17 March 2014; published: 15 June 2014

Subject Editor: Vazrick Nazari

\begin{abstract}
A detailed study of specimens from several regions of the distribution of Ochromolopis zagulajevi Budashkin \& Sachkov, 1991 and O. ictella (Hübner, 1813) shows that O. ictella and O. zagulajevi are parapatric species with overlapping distribution in the Balkan Peninsula. Details of morphological and molecular differences as well as a distribution map with locations of the examined specimens are given.
\end{abstract}

\section{Introduction}

Ochromolopis Hübner, 1825 is one of the 11 described genera of Epermeniidae Spuler, 1910, a family currently comprising 188 species and distributed worldwide. It is the only family within the superfamily Epermenioidea Minet, 1983, which, according to Dugdale et al. (1998), shows indications of affinities with the alucitoid/pterophoroid assemblage, but the family placement has not received any support in recent molecular studies across all of Lepidoptera (Mutanen et al. 2010; Regier et al. 2013). The potential autapomorphies of Epermeniidae are the following: hind tibia with stiff bristles; forewing fringe with groups of lamellar scales; larval submentum with posterior protuberance; prothoracic prespiracular L group bisetose; pupa unspined, abdominal segments I-IV immovable, segment IX with characteristic paired lateral pits (Dugdale et al. 1998). The majority of species bear tufts or raised scales on the dorsum of forewings. Further characteristics are the loss of one of the apical forewing veins (M3 and Cu1 fused) and the widening of the ventral branch of anterior apophysae in females. The genus Ochromolopis currently comprises 11 species, with four of them distributed in the Palaearctic region, while the others have a Nearctic, Afrotropical and Oriental distribution.

We examined Ochromolopis ictella (Hübner, 1813) and O. zagulajevi Budashkin \& Sachkov, 1991. The two species are closely related and not distinguishable superficially. Only the genital morphology shows clear differences. A more detailed study was made to determine the variability within the two taxa not only by using the traditional methods of morphological investigation but also by means of molecular methods (DNA Barcoding) by the second author. 


\section{Material and methods}

The examined material originates from numerous collections and was provided by museum curators as well as by private collectors. A list of examined material is given in the appendix.

\section{Morphological methods}

Genitalia of both sexes were dissected in order to study morphological variability. Phallus and valvae were removed from the genitalia capsule (uncus-tegumen-vinculum with saccus) during dissection. The ring-shaped connection of tegumen-vinculum was not cut laterally but kept intact. Drawings (all at the same scale) were made from genitalia of the two taxa and their variation was compared.

\section{Molecular methods}

For the molecular investigation of relationships between Ochromolopis ictella and O. zagulajevi we analysed the Barcode fragment of the mitochondrial COI gene. In order to obtain a high quantity of DNA, we performed the DNA extraction on the abdomen of dried specimens, followed by genital dissection from the macerated abdomen, as suggested by Knölke et al. (2005). DNA was extracted using the Macherey-Nagel NucleoSpin Tissue kit according to the manufacturer's suggestions. PCR amplification of an approximately 630 base pair (bp) fragment of the COI barcode sequence was done with the primer pair HybLCO/Nancy or in the case of fragmented DNA with the primer pairs HybLCO/K699 and Ron/Nancy, respectively (Folmer et al. 1994; Mitchell et al. 2005; Simon et al. 1994). The sequences were amplified with BIO-X-ACT Short DNA polymerase (Bioline). The PCR program for BIO-X-ACT Short DNA polymerase corresponds to the manufacturer's guidelines in conjunction with the respective primer annealing temperature of $48^{\circ} \mathrm{C}$. The PCR products were checked for amplification success via gel electrophoresis on a 1\% agarose gel, subsequent staining with GelRed, and final examination under UV light. The PCR products were cleaned with ExoSAP-IT (USB Corporation). The sequence PCR was performed with BigDye Terminator v3.1 Cycle Sequencing Kit (Applied Biosystems). After final sodium acetate-ethanol clean-up of the samples, sequencing was carried out on a 3130 Genetic Analyzer (Applied Biosystems). A Mastercycler ep gradient S (Eppendorf) was used for PCR amplifications, ExoSAP-IT clean-up and sequence PCR.

Sequence alignment was carried out manually with PhyDE 0.9971 (Müller et al. 2008). Calculation of the genetic distances as well as of the dendrogram using the Neighbor-Joining (NJ) method (Saitou \& Nei 1987; Studier \& Keppler 1988) were performed under the uncorrected-p (uncorr-p) model (Srivathsan \& Meier 2012) in PAUP* 4.0b10 (Swofford 2002). Ochromolopis kaszabi Gaedike, 1973 was included in the analysis as an outgroup and for comparison of the genetic distances of the two investigated taxa to a more distantly related species. 


\section{Distribution mapping}

In order to examine the distributional pattern of Ochromolopis ictella and O. zagulajevi, collection localities were compiled from labels of studied specimens and from literature. Geographical coordinates of these collection localities were obtained via Google Earth, Version 5.2.1.1588 and subsequently plotted on a map using DIVA-GIS, Version 7.2.3 (Hijmans et al. 2004).

$\begin{array}{ll}\begin{array}{l}\text { Abbreviations } \\ \text { coll. Arenberger } \\ \text { coll. Bengtsson } \\ \text { coll. Schmitz }\end{array} & \text { Ernst Arenberger, Vienna, Austria } \\ \text { ETHZ } & \text { Wengt Å. Bengtsson, Färjestaden, Sweden } \\ \text { FMNH } & \text { Eidgenössische Technische Hochschule, Zürich, Switzerland } \\ \text { HNHM } & \text { Finnish Museum of Natural History, Helsinki, Finland } \\ \text { LMAD } & \text { Hungarian National History Museum, Budapest, Hungary } \\ \text { MNG } & \text { Löbbecke Museum und Aquazoo, Düsseldorf, Germany } \\ \text { MTD } & \text { Museum der Natur, Gotha, Germany } \\ \text { NHMB } & \text { Museum für Tierkunde, Senckenberg Naturhistorische Sammlungen Dresden, Germany } \\ \text { NHRS } & \text { Naturhistorisches Museum Basel, Switzerland } \\ \text { NMEG } & \text { Naturhistoriska Riksmuseet, Stockholm, Sweden } \\ \text { NMPC } & \text { Naturkundemuseum, Erfurt, Germany } \\ \text { NMW } & \text { National Museum (Natural History), Prague, Czech Republic } \\ \text { SDEI } & \text { Naturhistorisches Museum, Vienna, Austria } \\ \text { SMNK } & \text { Senckenberg Deutsches Entomologisches Institut, Müncheberg, Germany } \\ \text { SMNS } & \text { Staatliches Museum für Naturkunde, Karlsruhe, Germany } \\ \text { TLMF } & \text { Staatliches Museum für Naturkunde, Stuttgart, Germany } \\ \text { ZIN } & \text { Tiroler Landesmuseum Ferdinandeum, Innsbruck, Austria } \\ \text { ZMHB } & \text { Zoological Institute, Russian Academy of Sciences, St. Petersburg, Russia } \\ \text { ZMUC } & \text { Museum für Naturkunde der Humboldt-Universität, Berlin, Germany } \\ \text { ZSM } & \text { Zoological Museum, Copenhagen, Denmark } \\ & \text { Zoologische Staatssammlung, Munich, Germany }\end{array}$

\section{Results}

\section{Redescription of morphology}

The two taxa do not differ in superficial appearance (see Fig. 1 for a specimen of $O$. ictella). Head, thorax, abdomen dark grey, shiny, forewing lead-grey, shiny, with two longitudinal golden-yellowish stripes: the first obliquely extending from base to dorsum shortly before half of wing, where first tuft of raised scales is situated, the second running parallel, initiating at $1 / 3$ of cell, pointing straight towards outer margin and ending well before apex. The distal end of first stripe connected with the proximal end of the second stripe, forming a sustained Z. O. ictella and O. zagulajevi only differ in the shape of the genitalia (ictella: Figs 2-9, 19-21, 30; zagulajevi: Figs 10-18, 22-29, 31-32).

According to Budashkin \& Sachkov (1991), O. zagulajevi has an area of numerous strongly sclerotized cornuti in the phallus within the posterior half of the vesica (Fig. 12). We found that, 


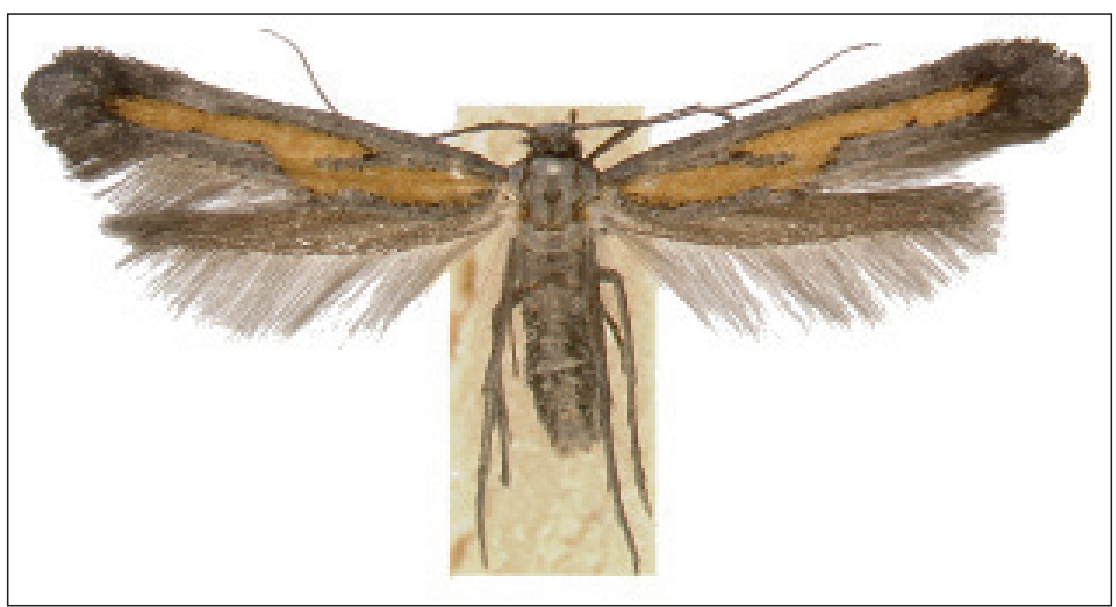

Figure 1. Ochromolopis ictella, imago.

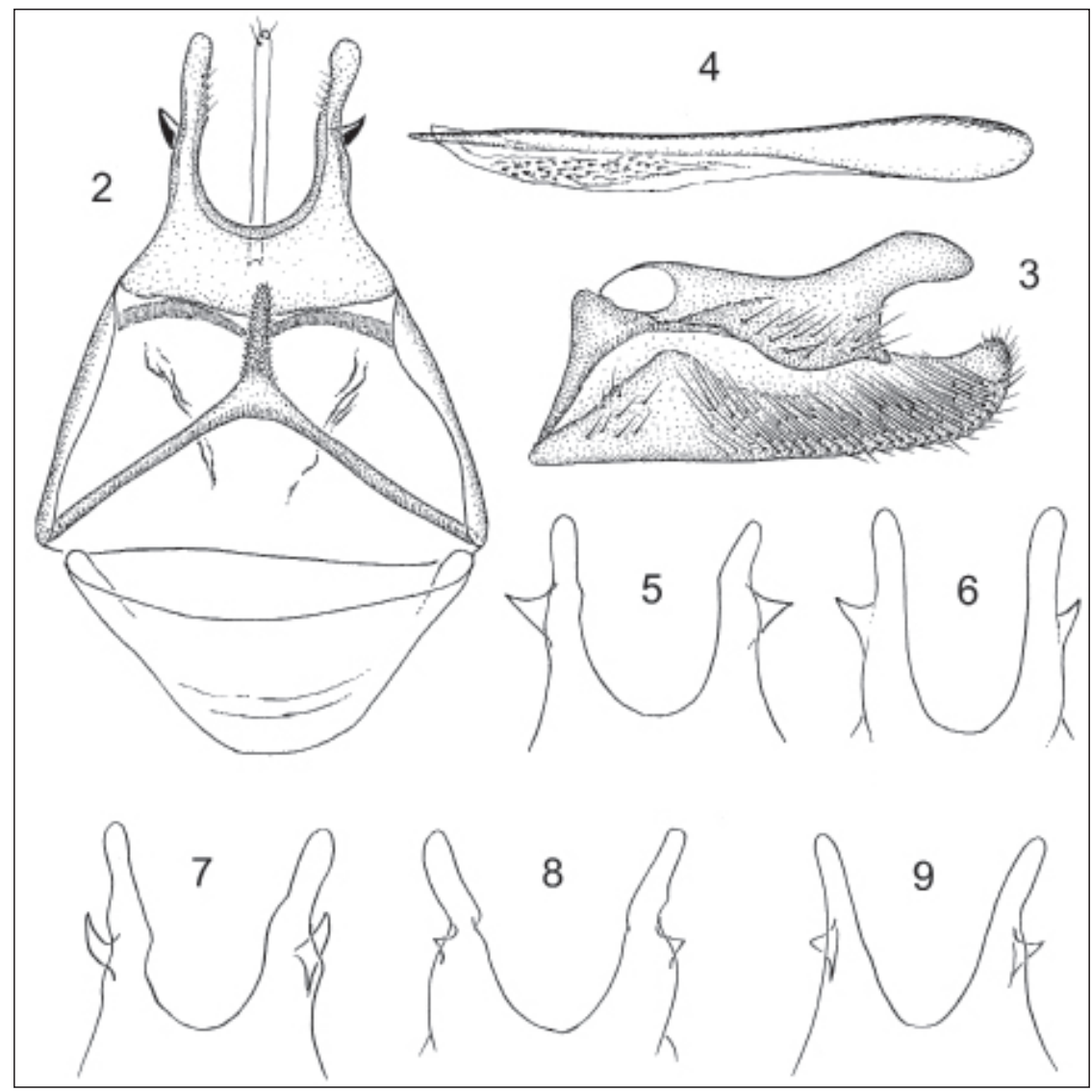

Figures 2-9. Male genitalia of Ochromolopis ictella. 2-4. specimen from Zljeb, Montenegro: 2. uncus-tegumen-vinculum. 3. valva. 4. phallus. 5-9. variability in socii shape: 5. Xauen A'Faska, Mauretania. 6. Piedmont, Italy. 7. Neustadt, Germany. 8. Naumburg, Germany. 9. Vienna, Austria. 


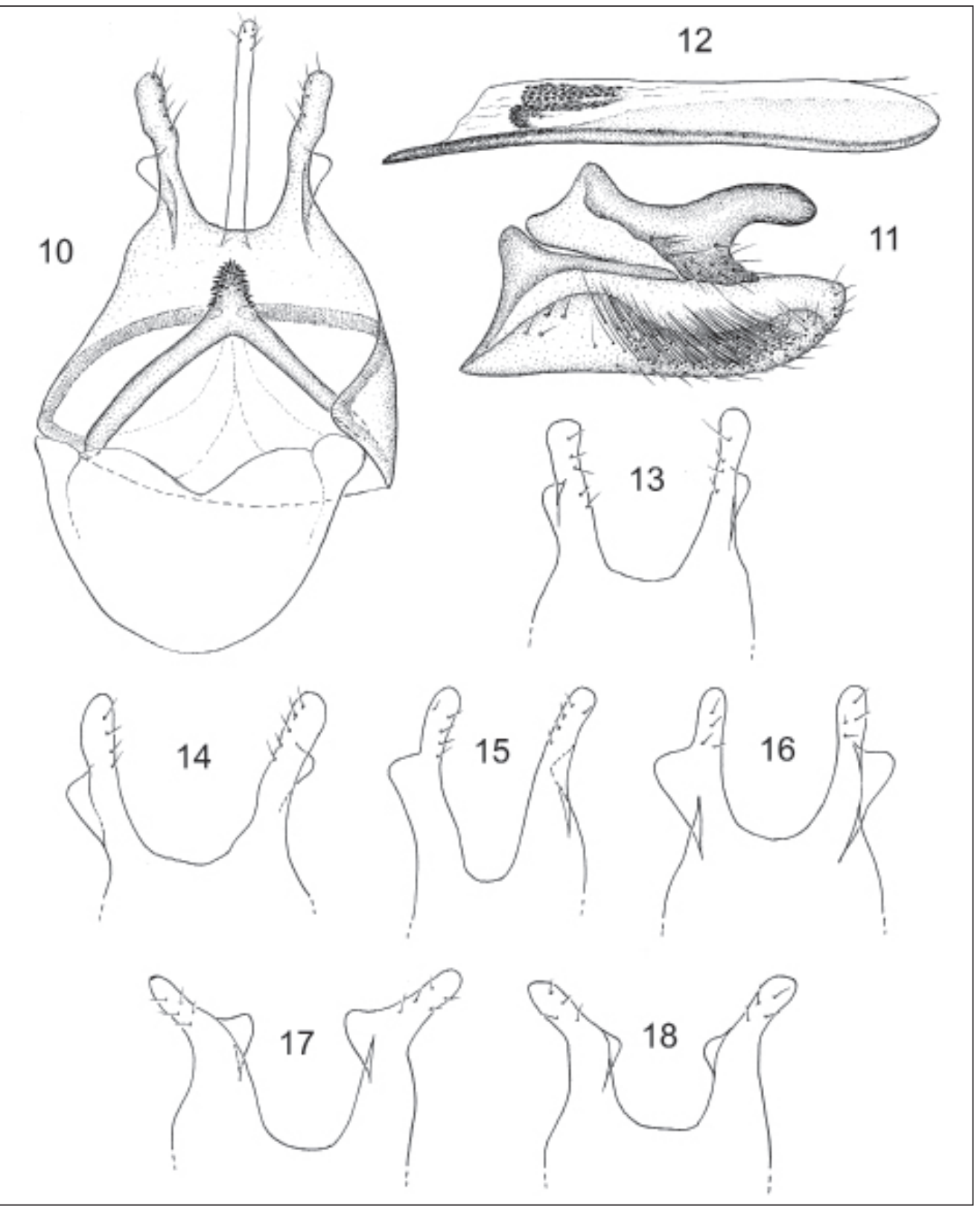

Figures 10-18. Male genitalia of Ochromolopis zagulajevi. 10-12. specimen from Crimea, Ukraine: 10. uncus-tegumen-vinculum. 11. valva. 12. phallus. 13-18. variability in socii shape: 13. Danubian delta, Romania. 14-15, 17. Kabardino-Balkarskij Nat. Res., Russia. 16. Crimea, Ukraine. 18. Djanik, Turkey.

due to the posteriad evertability of the vesica, the position of the cornuti may vary between different genital dissections. Characteristic for zagulajevi is the large quantity of cornuti.

In most cases the cornuti are in a more or less compact cluster, concentrated in the proximal fourth of the phallus, but in some cases the area of cornuti in the vesica covers the second- to 


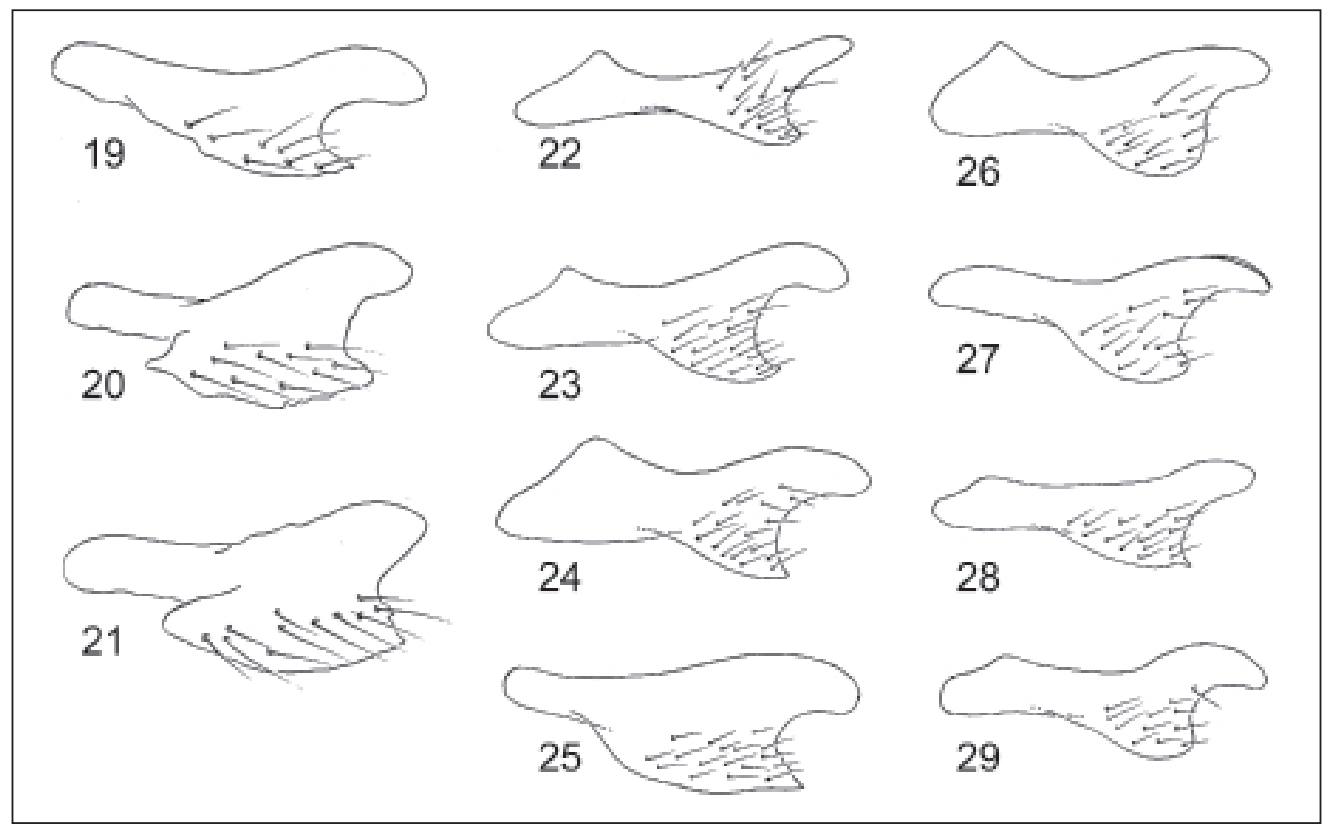

Figures 19-29. Variability in costa shape. 19-21. variability within Ochromolopis ictella: 19. Neustadt, Germany. 20. Vienna, Austria. 21. Naumburg, Germany. 22-29. variability within O. zagulajevi: 22-24. Kabardino-Balkarskij nat.res., Russia. 25. Northern Adriatic, Croatia. 26. Crimea, Ukraine. 27. Djanik, Turkey. 28. Gjalica Ljums, Albania. 29. Danubian delta, Romania.

third-fourth of the phallus length. The vesica of ictella also exhibits minute cornuti, but their number is mostly smaller, and they are not arranged as compactly as in zagulajevi (Fig. 4).

The shape of the narrow socii allows for an easier differentiation. In zagulajevi the socii have a dorsally attached lobe-shaped process at half of their length, which varies in size and shape (Figs 13-18). In contrast, in ictella this process is thorn- or hook-shaped and has a pointed tip, and is also variable in size and shape (Figs 5-9). The shape of the costal arm of the valva, which is nearly as long as the valva itself, is variable in both taxa. However, the costal arm appears to be more compact in ictella than in zagulajevi.

The female genitalia of the two taxa also exhibit some structural differences: in O. zagulaje$v i$, the posterior part of ductus bursae is more strongly sclerotized, but sometimes the posterior sclerotization of the ductus is not developed (compare Figs 31 and 32); the median part is wrinkled and covered with numerous minute semicircular sclerotizations. In contrast, O. ictella lacks strong sclerotization in the posterior ductus bursae and the wrinkles at the median part are weakly developed and have minute sclerotizations (Fig. 30).

In order to evaluate the significance of the investigated morphological characters for defining the taxonomic status of the two taxa it was deemed important to include a third taxon into the treatment, Ochromolopis kaszabi Gaedike, 1973. This species was described from Mongolia, and its currently known distribution ranges from Altai through Mongolia to Russian Far East and China. Superficially, O. kaszabi is not distinguishable from the above mentioned taxa, but it shows clear differences in the male genital structures: socii are broad, more or less parallel, nearly obliquely truncated, with a more or less pointed tip, depending on preparation 


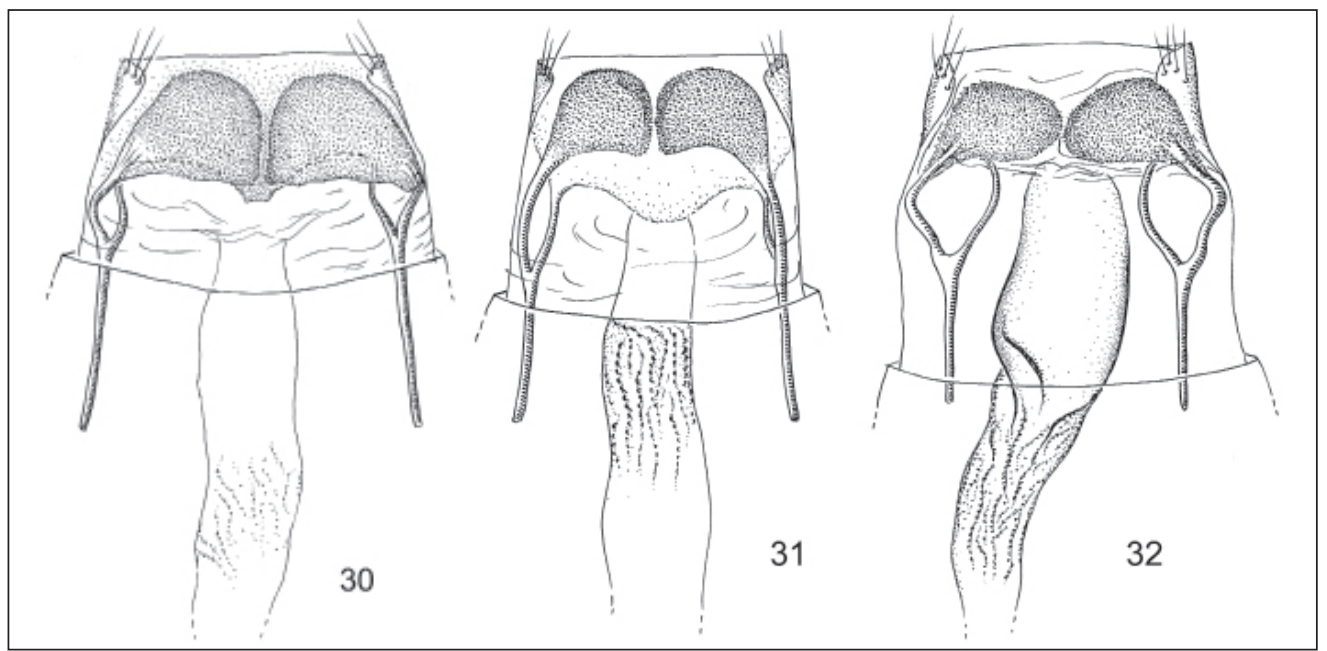

Figures 30-32. Female genitalia. 30. Ochromolopis ictella (Abruzzi, Italy). 31-32. variability within $O$. zagulajevi: 31. Crimea, Ukraine. 32. Greece.

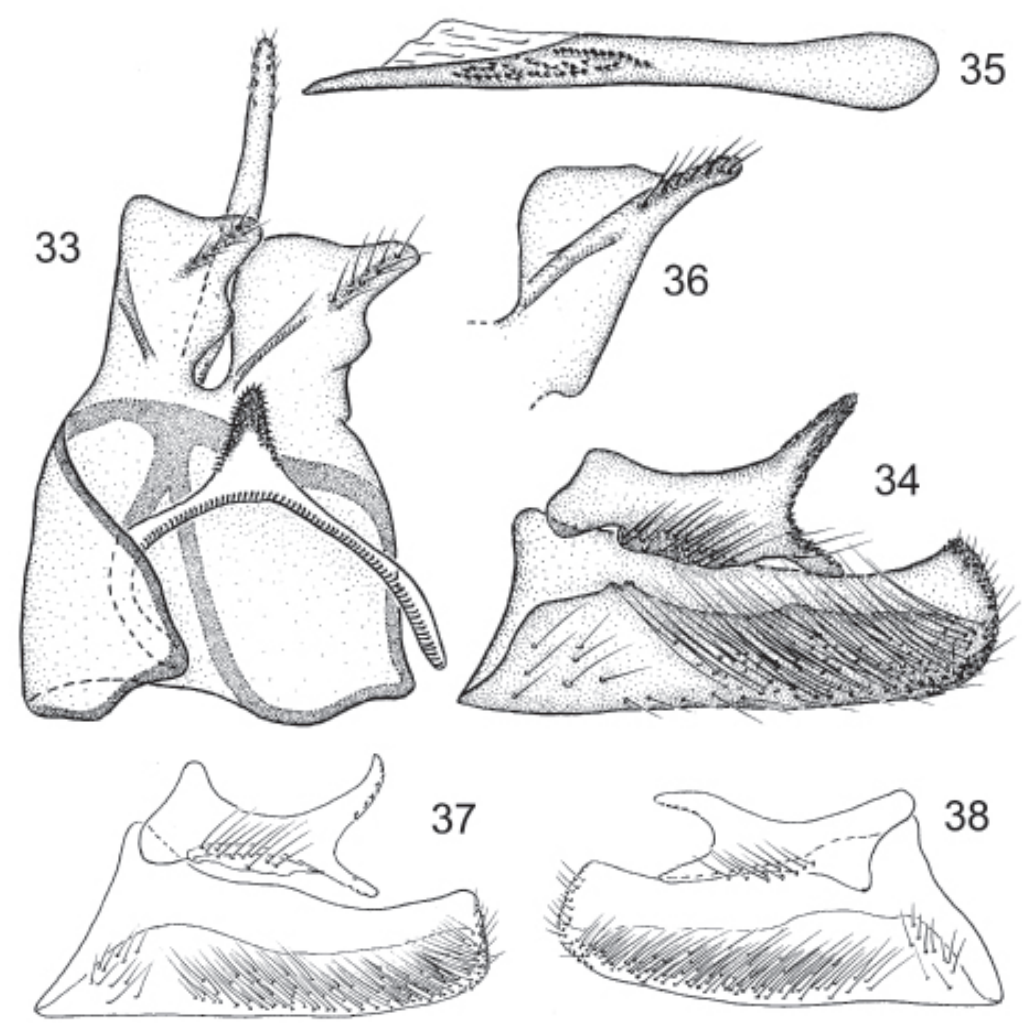

Figures 33-38. Male genitalia of Ochromolopis kaszabi (Mongolia; according to Gaedike, 1973). 33. uncus-tegumen-vinculum. 34. valva. 35. phallus. 36. variable form of socius. 37-38. variability of valva (Hoengshan, China). 
Table 1. DNA barcoding specimen information.

\begin{tabular}{|c|c|c|c|c|}
\hline Taxon & $\begin{array}{l}\text { DNA specimen } \\
\text { voucher }\end{array}$ & Origin, date, collector & \begin{tabular}{|c|}
$\begin{array}{c}\text { Sequence } \\
\text { length }\end{array}$ \\
\end{tabular} & $\begin{array}{c}\text { GenBank } \\
\text { accession no. }\end{array}$ \\
\hline \multirow{4}{*}{ ictella } & MTD Lep1073 & $\begin{array}{c}\text { Italy, Piedmont, Valdieri, reserve, } 850 \mathrm{~m} \text { 29.-30.vi.2008, leg. } \\
\text { O. Karsholt }\end{array}$ & $612 \mathrm{bp}$ & KF511936 \\
\hline & ZSM Lep 27010 & $\begin{array}{c}\text { Germany, Bavaria, Oberpfalz, Nittendorf, 400m, 08.vi.1994, } \\
\text { leg. A. Segerer }\end{array}$ & $658 \mathrm{bp}$ & HM902062 \\
\hline & TLMF Lep 05228 & $\begin{array}{c}\text { Macedonia, Mavrovo NP, Korab, summit ridge, 2700m, } \\
\text { 28.vii.2011, leg. P. Huemer \& G. Tarmann }\end{array}$ & $658 \mathrm{bp}$ & KJ427720 \\
\hline & TLMF Lep 05229 & $\begin{array}{c}\text { Macedonia, Mavrovo NP, Korab, summit ridge, 2700m, } \\
\text { 28.vii.2011, leg. P. Huemer \& G. Tarmann }\end{array}$ & $658 \mathrm{bp}$ & KJ427721 \\
\hline \multirow{9}{*}{ zagulajevi } & MTD Lep1071 & $\begin{array}{c}\text { Croatia, Istria, Belavići, Marčana, 08.-14.ix.2008, leg. W. } \\
\text { Mey }\end{array}$ & $612 \mathrm{bp}$ & KF511934 \\
\hline & MTD Lep1072 & $\begin{array}{c}\text { Croatia, Istria, Belavići, Marčana, 08.-14.ix.2008, leg. W. } \\
\text { Mey }\end{array}$ & $612 \mathrm{bp}$ & KF511935 \\
\hline & MTD Lep1074 & Italy, Lucania, Mt. Pollino, 780m, 03.x.2010, leg. P. Skou & $612 \mathrm{bp}$ & KF511937 \\
\hline & MTD Lep1075 & Italy, Lucania, Mt. Pollino, 780m, 03.x.2010, leg. P. Skou & $612 \mathrm{bp}$ & KF511938 \\
\hline & MTD Lep1076 & $\begin{array}{c}\text { SW Bulgaria, Pirin Sandanski, Ilindentsi, 500m, 28.iii.-04. } \\
\text { iv.2011, leg. N. Savenkov }\end{array}$ & $612 \mathrm{bp}$ & KF511939 \\
\hline & MTD Lep1077 & $\begin{array}{c}\text { SW Bulgaria, Pirin Sandanski, Ilindentsi, 500m, 28.iii.-04. } \\
\text { iv.2011, leg. N. Savenkov }\end{array}$ & $612 \mathrm{bp}$ & KF511940 \\
\hline & MTD Lep1078 & $\begin{array}{c}\text { SW Bulgaria, Pirin, Sandanski, Ploski, 250m, 17.-31.v.2010, } \\
\text { leg. N. Savenkov }\end{array}$ & $612 \mathrm{bp}$ & KF511941 \\
\hline & MTD Lep1079 & $\begin{array}{c}\text { SW Bulgaria, Pirin Sandanski, Ilindentsi, 500m, 28.iii.-04. } \\
\text { iv.2011, leg. N. Savenkov }\end{array}$ & $612 \mathrm{bp}$ & KF511942 \\
\hline & MTD Lep1080 & $\begin{array}{c}\text { SW Bulgaria, Pirin, Sandanski, Ploski, 250m, 17.--31.v.2010, } \\
\text { leg. N. Savenkov }\end{array}$ & $591 \mathrm{bp}$ & KF511943 \\
\hline kaszabi & MTD Lep1081 & $\begin{array}{l}\text { Russia, Siberia, Chita, Ingoda river, 27.vii.1997, leg. I. } \\
\text { Kostjuk }\end{array}$ & $612 \mathrm{bp}$ & KF511933 \\
\hline
\end{tabular}

(see Figs 33 and 36). The costal arm of the valva is about two thirds of the valval length and has a forked distal end with a short ventral branch and a longer costal branch with pointed tip, directed more or less obliquely upwards, edges of the two branches with minute pointed thorns. The shape of the costal arm is variable (see Figs 37-38). Female genitalia (according to the description in Budashkin \& Sachkov 1991: figs 3, 4) are characterised by the ductus bursae lacking strong sclerotization, but with strongly sclerotized sternal segments.

\section{Molecular results}

The barcode sequences length was 591-658 bp (see Table 1). No indels have been observed in any of the sequences. All obtained barcode sequences have been submitted to GenBank (for accession numbers see Table 1).

In the NJ analysis we obtained two clusters comprising 6 and 7 samples, respectively (Fig. 39). The two clusters do not correspond to the two taxa. Rather, in one cluster there are two Ochromolopis ictella and five $O$. zagulajevi specimens, and in the other cluster there are two $O$. ictella and four $O$. zagulajevi specimens. In O. zagulajevi we observed two cases in which specimens from the same locality and period of collection are not found in the same Barcode cluster: 1) Lep1075 versus Lep1074 (Italy, Mt. Pollino) and 2) Lep1076 \& Lep1079 versus Lep1077 (Bulgaria, Ilindentsi).

Intraspecific divergences within ictella range from $0.168 \%$ to $1.672 \%$ and in zagulajevi from $0 \%$ to $1.359 \%$ (see Table 2). Interspecific uncorr-p divergences between ictella and zagulajevi 


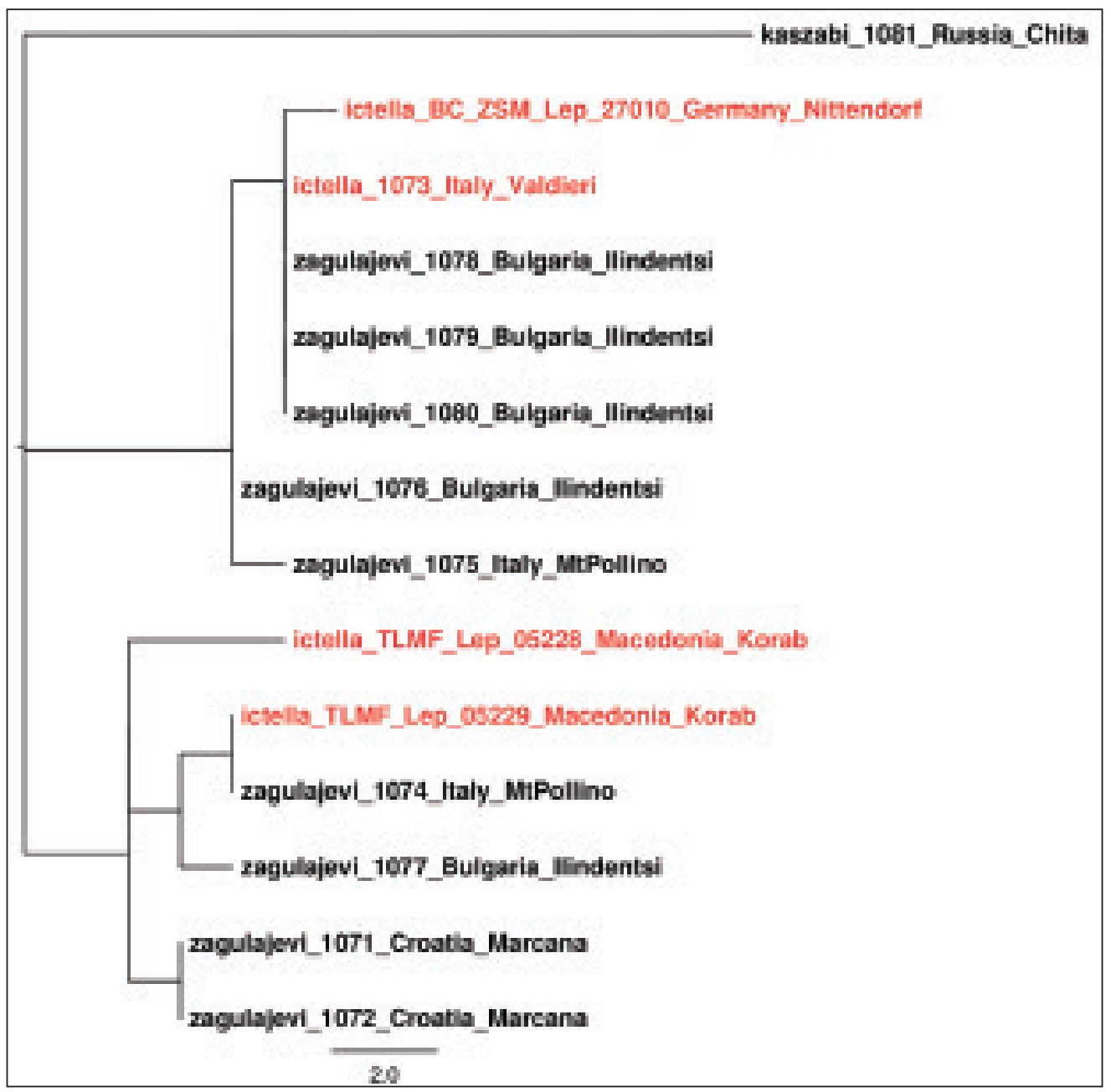

Figure 39. NJ dendrogram, based on uncorrected-p distances; scale bar represents $2.0 \%$ uncorrected-p distance.

range from $0 \%$ to $1.528 \%$. In contrast, O. kaszabi has a Barcode divergence of $2.922-3.100 \%$ with ictella and 2.451-3.045\% with zagulajevi.

\section{Distribution map}

The map of the investigated taxa (Fig. 40) shows that Budashkin \& Sachkov's (1991) presumption in the original description of $O$. zagulajevi concerning the distribution was right. All examined specimens from Caucasus region, Crimea, Iran, Turkey, and Southern Europe (Greece, Bulgaria, Albania, S-Italy) belong to O. zagulajevi. On the contrary, all examined specimens from North Africa, southwestern, central and northern Europe (Spain, France, Switzerland, Denmark, Finland, Germany, Austria, N-Italy, Poland, Czech Republic, Slovakia, Hungary), and Montenegro (only one specimen studied) belong to O. ictella . 
Table 2. Uncorrected-p sequence divergence matrix with divergence values as percentage.

\begin{tabular}{|c|c|c|c|c|c|c|c|c|c|c|c|c|c|}
\hline & $\begin{array}{l}1081 \\
\text { kaszabi }\end{array}$ & $\begin{array}{l}1073 \\
\text { ictella } \\
\end{array}$ & $\begin{array}{l}27010 \\
\text { ictella }\end{array}$ & $\begin{array}{l}05228 \\
\text { ictella }\end{array}$ & $\begin{array}{l}05229 \\
\text { ictella }\end{array}$ & $\begin{array}{l}1071 \\
\text { zagul. }\end{array}$ & $\begin{array}{l}1072 \\
\text { zagul. }\end{array}$ & $\begin{array}{l}1074 \\
\text { zagul. }\end{array}$ & $\begin{array}{l}1075 \\
\text { zagul. }\end{array}$ & $\begin{array}{l}1076 \\
\text { zagul. }\end{array}$ & $\begin{array}{l}1077 \\
\text { zagul. }\end{array}$ & $\begin{array}{l}1078 \\
\text { zagul. }\end{array}$ & $\begin{array}{l}1079 \\
\text { zagul. }\end{array}$ \\
\hline $\begin{array}{l}\text { ictella MTD } \\
\text { Lep1073 }\end{array}$ & 2.941 & & & & & & & & & & & & \\
\hline $\begin{array}{l}\text { ictella ZSM } \\
27010 \\
\end{array}$ & 3.083 & 0.168 & & & & & & & & & & & \\
\hline $\begin{array}{l}\text { ictella TLMF } \\
05228\end{array}$ & 3.100 & 1.476 & 1.672 & & & & & & & & & & \\
\hline $\begin{array}{l}\text { ictella TLMF } \\
05229\end{array}$ & 2.922 & 1.299 & 1.520 & 0.760 & & & & & & & & & \\
\hline $\begin{array}{l}\text { zagulajevi MTD } \\
\text { Lep1071 }\end{array}$ & 2.451 & 1.144 & 1.295 & 0.654 & 0.477 & & & & & & & & \\
\hline $\begin{array}{l}\text { zagulajevi MTD } \\
\text { Lep1072 }\end{array}$ & 2.451 & 1.144 & 1.295 & 0.654 & 0.477 & 0.000 & & & & & & & \\
\hline $\begin{array}{l}\text { zagulajevi MTD } \\
\text { Lep1074 }\end{array}$ & 2.941 & 1.307 & 1.465 & 0.822 & 0.000 & 0.490 & 0.490 & & & & & & \\
\hline $\begin{array}{l}\text { zagulajevi MTD } \\
\text { Lep1075 }\end{array}$ & 2.941 & 0.327 & 0.490 & 1.477 & 1.300 & 1.144 & 1.144 & 1.307 & & & & & \\
\hline $\begin{array}{l}\text { zagulajevi MTD } \\
\text { Lep1076 }\end{array}$ & 2.778 & 0.163 & 0.326 & 1.313 & 1.136 & 0.980 & 0.980 & 1.144 & 0.163 & & & & \\
\hline $\begin{array}{l}\text { zagulajevi MTD } \\
\text { Lep1077 }\end{array}$ & 2.941 & 1.307 & 1.465 & 0.822 & 0.323 & 0.490 & 0.490 & 0.327 & 1.307 & 1.144 & & & \\
\hline $\begin{array}{l}\text { zagulajevi MTD } \\
\text { Lep1078 }\end{array}$ & 2.941 & 0.000 & 0.168 & 1.476 & 1.299 & 1.144 & 1.144 & 1.307 & 0.327 & 0.163 & 1.307 & & \\
\hline $\begin{array}{l}\text { zagulajevi MTD } \\
\text { Lep1079 }\end{array}$ & 2.941 & 0.000 & 0.168 & 1.476 & 1.299 & 1.144 & 1.144 & 1.307 & 0.327 & 0.163 & 1.307 & 0.000 & \\
\hline $\begin{array}{l}\text { zagulajevi MTD } \\
\text { Lep1080 }\end{array}$ & 3.045 & 0.000 & 0.172 & 1.528 & 1.351 & 1.187 & 1.187 & 1.359 & 0.338 & 0.170 & 1.356 & 0.000 & 0.000 \\
\hline
\end{tabular}

In Croatia and in Macedonia both taxa occur sympatrically. Additional sympatrical distribution might be present in Italy, where $O$. ictella is present from the northern part southwards to Umbria, and $O$. zagulajevi in the southern regions and Sicily. No material was available from Slovenia.

\section{Discussion}

The comparison of genital morphology between the two species reveals broad concordance of the investigated structures. Only one differing feature was found between $O$. ictella and O. zagulajevi, namely the shape of the socii within male genitalia. The divergence in genital morphology is evidently larger between $O$. kaszabi and the O. ictella-zagulajevi complex than between ictella and zagulajevi.

The analysis of DNA Barcodes reveals that the range of interspecific Barcode divergence between ictella and zagulajevi (0-1.528\%) is within the range of intraspecific divergence of $0.168-1.672 \%$ in ictella and $0-1.359 \%$ in zagulajevi. This suggests that it is possible that these two taxa might actually represent one somewhat variable species. However, the finding of one constant morphological difference in the male genitalia between ictella and zagulajevi and the sympatric occurrence of both taxa on the Balkan peninsula imply the validity of their species status. 


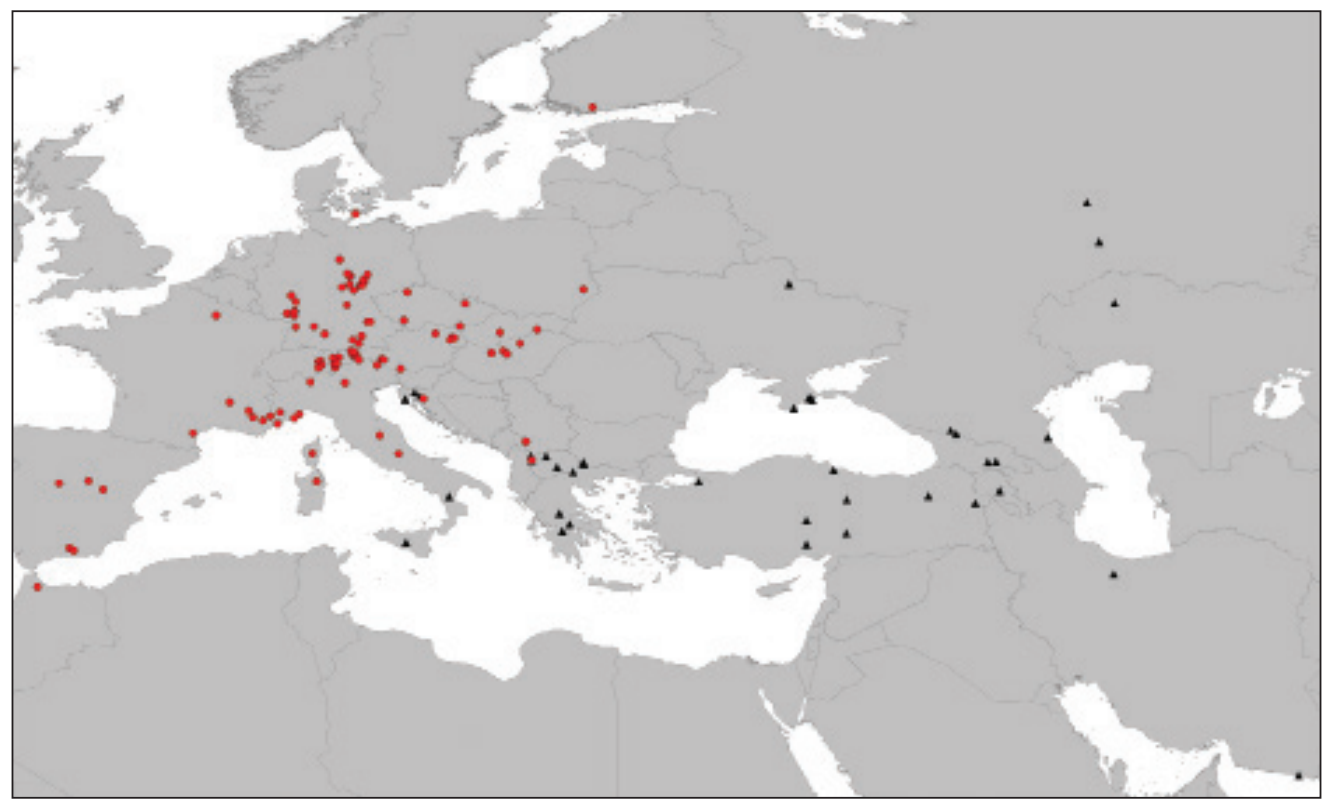

Figure 40. Distribution map of Ochromolopis ictella (red circles) and O. zagulajevi (black triangles) in the West Palaearctic.

Until further molecular work with much greater specimen sampling, focusing on establishing reasons behind the two DNA barcoding clusters (e.g., incomplete lineage sorting; Funk \& Omland 2003), can provide more data on the status of the two species, we recommend no change in their taxonomic status. Future work should also aim to infer a more accurate distribution border between these two taxa in Europe, especially in the areas of Central Italy southwards, of the Balkan Peninsula and from Slovenia and Hungary eastwards.

\section{Acknowledgements}

The study was only possible through the kind support of numerous entomologists by loaning material of the examined taxa. For this important help we thank the custodians of the museums listed in the Abbreviations section as well as Ernst Arenberger (Vienna, Austria), Bengt Å. Bengtsson (Färjestaden, Sweden), Hartmut Roweck (Kiel, Germany) and Willibald Schmitz (Bergisch-Gladbach, Germany). For the provision of DNA Barcoding data and the respective specimens for their use in this study we thank Peter Huemer (Innsbruck, Austria) and Andreas Segerer (Munich, Germany). We thank Matthias Nuss for the support of the molecular analyses in the DNA laboratory of the MTD and Christian Kutzscher (SDEI Müncheberg) for making the colour picture. We are also thankful to the reviewers for their valuable comments.

\section{References}

Budashkin JuI, Sachkov SA (1991) Novyje taksony zontitschnych molej roda Ochromolopis (Lepidoptera, Epermeniidae) fauny SSSR i opredelenije blizkich vidov [New taxa of moth from genus Ochromolopis (Lepidoptera, Epermeniidae) in the USSR fauna and identification of similar species]. Zoologitscheskij Zhurnal 70 (10): 78-83. 
Dugdale JS, Kristensen NP, Robinson GS, Scoble MJ (1998) 13. The Smaller Microlepidoptera-Grade Superfamilies. In Kristensen NP (ed). Lepidoptera, Moths and Butterflies. Volume 1: Evolution, Systematics, and Biogeography. Handbook of Zoology, vol. IV Arthropoda: Insecta, Part 35. Berlin, New York, Walter de Gruyter 217-232, 4 figs.

Folmer O, Black MB, Hoch W, Lutz RA, Vrijehock RC (1994) DNA primers for amplification of mitochondrial cytochrome $\mathrm{c}$ oxidase subunit I from diverse metazoan invertebrates. Molecular Marine Biology and Biotechnology 3: 294-299.

Funk DJ, Omland KE (2003) Species-level paraphyly and polyphyly: frequency, causes, and consequences, with insights from animal mitochondrial DNA. Annual Review of Ecology, Evolution and Systematics 34: 397-423. doi: 10.1146/annurev.ecolsys.34.011802.132421

Gaedike R (1973) 233. Epermeniidae, Acrolepiidae. Ergebnisse der zoologischen Forschungen von Dr. Z. Kaszab in der Mongolei (Lepidoptera). Mit einer Übersicht über die Epermeniidae- und Acrolepiidaefauna Ostasiens. Reichenbachia, Staatliches Museum für Tierkunde in Dresden 14 (12): 95-100.

Hijmans RJ, Guarino L, Bussink C, Mathur P, Cruz M, Barrentes I, Rojas E (2004) DIVA-GIS. Version 7.2.3. A geographic information system for the analysis of species distribution data. http://www. diva-gis.org/

Hübner J (1813) Sammlung europäischer Schmetterlinge, Vol. 8, Tineae. Augsburg. 71 pls.

Hübner J (1816-1826) [imprint „1816“]. Verzeichniß bekannter Schmettlinge [sic]. bey dem Verfasser zu finden, Augsburg. (Verzeichniß) [1]-[3]-4-6-[7]-8-431, (Anzeiger) [1]-2-72.

Knölke S, Erlacher S, Hausmann A, Miller MA, Segerer AH (2005) A procedure for combined genitalia dissection and DNA extraction in Lepidoptera. Insect Systematics \& Evolution 35: 401-409. doi: $10.1163 / 187631204788912463$

Minet J (1983) Étude morphologique et phylogénétique des organes tympaniques des Pyraloidea 1: Genéralitiés et homologies (Lepidoptera: Glossata).- Annales de la Société Entomologique de France (Nouvelle Série) 19: 175-207.

Mitchell A, McClay AS, Pohl GR, Sperling FAH (2005) PCR-based methods for identification of two Eteobalea species (Lepidoptera : Cosmopterigidae) used as biocontrol agents of weedy Linaria species (Scrophulariaceae). Canadian Entomologist 137: 129-137. doi: 10.4039/n03-104

Mutanen M, Wahlberg N, Kaila L (2010) Comprehensive gene and taxon coverage elucidates radiation patterns in moths and butterflies. Proceedings of the Royal Society of London B Biological Sciences 277: 2839-2848. doi: 10.1098/rspb.2010.0392

Müller K, Müller J, Neinhuis C, Quandt D (2008) PhyDE - Phylogenetic data editor, Version 0.9971. http://www.phyde.de/

Regier JC, Mitter C, Zwick A, Bazinet AL, Cummings MP, Kawahara AY, Sohn JC, Zwickl DJ, Cho S, Davis DR, Baixeras J, Brown J, Parr C, Weller S, Lees DC, Mitter KT (2013) A Large-Scale, Higher-Level, Molecular Phylogenetic Study of the Insect Order Lepidoptera (Moths and Butterflies). PLoS ONE 8: e58568. doi: 10.1371/journal.pone.0058568

Saitou N, Nei M (1987) The Neighbor-joining method: A new method for reconstructing phylogenetic trees. Molecular Biology and Evolution 4: 406-425.

Simon C, Frati F, Beckenbach A, Crespi B, Liu H, Flook P (1994) Evolution, weighting, and phylogenetic utility of mitochondrial gene sequences and a compilation of conserved polymerase chain reaction primers. Annals of the Entomological Society of America 87: 651-701.

Spuler A (1910) Die Schmetterlinge Europas. Schweizerbart'sche Verlagsbuchhandlung, Stuttgart.

Studier JA, Keppler KJ (1988) A note on the Neighbor-Joining algorithm of Saitou and Nei. Molecular Biology and Evolution 5: 729-731.

Swofford DL (2002) PAUP*. Phylogenetic Analysis Using Parsimony (*and Other Methods). Version 4. Sinauer Associates, Sunderland, Massachusetts.

Srivathsan A, Meier R (2012) On the inappropriate use of Kimura-2-parameter (K2P) divergences in the DNA-barcoding literature. Cladistics 28 (2): 190-194. doi: 10.1111/j.1096-0031.2011.00370.x 


\section{Appendix}

A list of examined specimens of Ochromolopis ictella (Hübner 1813), O. zagulajevi Budashkin \& Sachkov, 1991 and O. kaszabi Gaedike, 1973 follows below. All specimens were determined by R. Gaedike or were part of the original description of zagulajevi. The list contains material examined from approximately 1965 to 2013. The localities in this list are recorded as they appear on the labels. The current depository of the material (if available) is provided using the abbreviations listed in the Abbreviations section.

\section{Ochromolopis ictella (Hübner, 1813)}

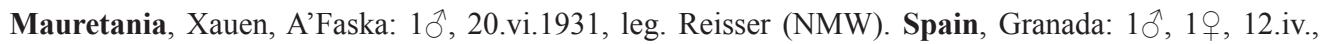
22.vi., leg. Staudinger (ZMHB); Escorial: $1 \mathcal{O}^{\hat{\alpha}}$, vii.1924; Castellon, 3km S of Forcall: 1 ㅇ, 16.vi.1989, leg. et coll. Bengtsson; Guadalajara, 1km NW Trillo: 1ð̂, 21.vii.1988, leg. Fibiger (ZMUC); Cuenca, $5 \mathrm{~km}$ SW Huelamo, by Rio Jucar: 1ㅇ, 19.vii.1988, leg. Fibiger (ZMUC); Sieddar Nevada, Camino de la Veleta: 1§̄, 1ㅇ, 29.vii.1985, 3.vii.1986, leg. Traugott-Olsen (ZMUC). France, Bourgogne: 1§, leg.

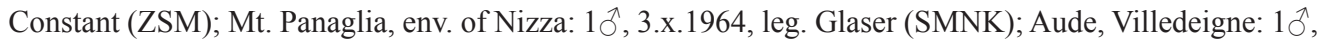
9.vii.1961, leg. Burmann (SMNK); La Voulte-sur-Rhône: 2 specimens, leg. Dresney; env. of Digne: Les Mees: 1ð̂, 20.v.1977, leg. Bruer (ZSM); Basses Alpes, la Baume: 2 specimens, 26.vii.1973, leg. Groß (LMAD); Alpes mar., St. Bres: 1 specimen, 24.vii.1973, leg. Groß (LMAD); Provence, 4km N Eyquians:

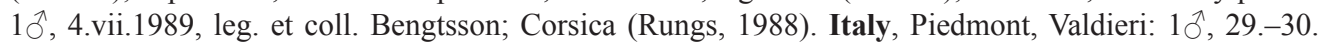
vi.2008, leg. Karsholt (ZMUC); Abruzzi, Mte Sirente: 1일. leg. Dannehl (ZSM); Liguria, Noli (Savona): 1ðึ, 21.-30.ix.1951, leg. Klimesch (ZSM); Liguria, Andora: 1ㅇ, 6.ix.1965, leg. Klimesch (ZSM). Montenegro, Zljeb, Neumontenegro: 1 $\delta^{\lambda}, 1916$, leg. Penther (NMW). Macedonia, NP Mavrovo, Korab, sum-

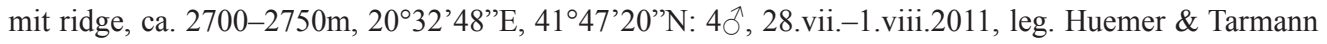
(TLMF). Austria, Wien: 4 $\sigma^{\Uparrow}$, leg. Mann (NMW); Lobau: $1 \hat{\jmath}, 1$, , viii.1916, leg. Predota (NMW); Möd-

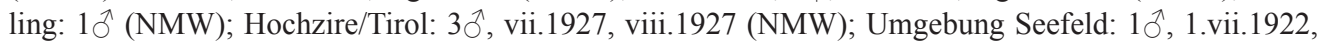
leg. Bauer (ZSM); Innsbruck: 1ð̂, 14.vi.1938, leg. Burmann (SMNK); Lechtaler Alpen, 1700m: 1ठ, 1 ,

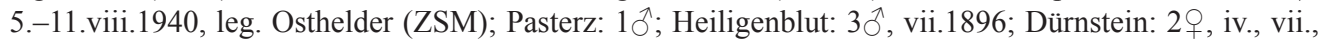
leg. Klimesch (ZSM); Brennersee, 1400m: 1ठ, 14.vii.1968, leg. Burmann (SMNK); Stuben/Vorarlberg, 1500m: 1 specimen, 11.viii.1962, leg. Groß (LMAD); Schütt near Villach: 1 specimen, 22.vii.1972, leg. Groß (LMAD); Tirol, Tessenberg: 1ิ̂, 12.-15.vii.1981, leg. Schnack (ZMUC). Switzerland, Kanton St. Gallen Vättnerberg: 1ठ̂, 12.viii.1909, leg. Müller-Rutz (NHMB); Vättis: 1ठ̂, 1, vii., leg. Müller-

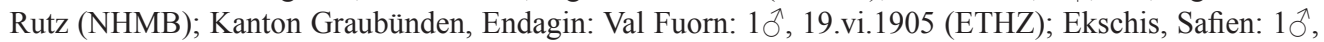
27.vi.1929, leg. Müller-Rutz (NHMB); Parpan: 1 đ̂, 1 ㅇ, vi.1920, vii.1920, leg. Müller-Rutz (NHMB); Fetan: 1 specimen, 31.vii. 1923, leg. Müller-Rutz (NHMB); Remüs: 1ठ̂, 1 , , vii. 1933, viii. 1935, leg. Weber (ETHZ); Mathon: 2ð̂, 3., 5.viii.1929, leg. Weber (ETHZ); Salorino: 1ð̂, 1q, 26.vii.1926, 13.vii.1927, leg. Weber (ETHZ). Czech Republic, Env. of Litomerice, Libochovany: 1 specimen, leg. Zimmermann (NMPC); Zalezly: 1 specimen, leg. Wihan; Lednice: 1 specimen, leg. Zimmermann (NMPC); Hrabasice: 1ð̄, v.1977 (ZMUC). Slovakia, Zadiel: 1 specimen, leg. Povólny; Cenko: 1 specimen, leg. Patocka; Banska Stiavnica: 1 specimen, leg. Patocka. Hungary, Budapest: 1ð̄, 18.v.1913, leg. Uhrik (HNHM); Csákvár: 1ð̂, 7.vii.1961, leg. Gozmány (HNHM); Puszta Peszér: 1ð̄, 10.vii.1929, leg. Osthelder (ZSM); Bagloyirtás, Mátra: 1ô, 12.vi.1951, leg. Gozmány (HNHM). Germany, Halle/Saale: 1 specimen, leg. Eichler (ZSM); Naumburg: 1 specimen, leg. Bauer (ZSM); Kyffhäuser: 5 specimens, leg. Hockermeyer / Lenthe / Beer / Petry / Soffner (NMEG; SDEI); Ochsenburg/Kyffhäuser: 1 specimen, leg. Sutter (SMNK); Bad Blankenburg: 1 specimen, leg. Steuer (ZMHB); Jena: 1 specimen, leg. Nikolaus (MNG); Inselsberg, Georgenthal: 1 specimen, leg. Lenthe (MNG); Alter Stolberg near Nordhausen: 1 specimen, leg. Petry (NMEG); env. of Erfurt: 1 specimen, leg. Beer (MNG); Löberschütz: 1 specimen, leg. Faulwetter; Tautenburg: 1 specimen, leg. Faulwetter; Flachsleite: 1 specimen, leg. Faulwetter; Gleisberg: 1 specimen, leg. Faulwetter; Totentäler, Kreis Nebra: 1 specimen, leg. Eichler (ZSM); Braunschweig: 1 specimen, leg. 
Heinemann; Neustadt/Haardt: 1 specimen, leg. Eppelsheim (ZSM); Kaiserlautern: 1 specimen, leg. Heuser; Grünstadt: 1 specimen, leg. Wörz (SMNS); Hambach: 1 specimen, leg. Wörz (SMNS); Battenberg: 1 specimen, leg. Wörz (SMNS); Wiesbaden: 1 specimen, leg. Wörz (SMNS); Stuttart: 1 specimen, leg. Wörz (SMNS); Schelklingen: 1 specimen, leg. Wörz (SMNS); Baden: 1 specimen, leg. Hering (ZMHB); Ascholding: 1 specimen, leg. Osthelder (ZSM); Steinebach: 1 specimen, leg. Osthelder (ZSM); Garchinger Heide: 1 specimen, leg. Osthelder (ZSM); Garmisch: 1 specimen, leg. Osthelder (ZSM); Mittenwald: 1 specimen, leg. Osthelder (ZSM); Regensburg: 1 specimen (ZSM); Ruhpolding: 1 specimen (ZSM); Bamberg: 1 specimen, leg. Garthe (ZSM). Poland, Katy, distr. Zamosc: 1§, 4.viii.1978, leg. Buszko (ZMUC). Denmark, Lolland, Rodbyhaven: 1 specimen, vii 2010, leg. Larsen ( ZMUC). Finland, Karislojo: $1{ }^{\lambda}, 12 . v i i i .1967$, leg. et coll. Krogerus.

\section{Ochromolopis zagulajevi Budashkin \& Sachkov, 1991}

Italy, Lucania, Mt. Pollino, 3950'N, 13³3'E: 4^’, 3.x.2010, 26.vii.2011, leg. Skou (ZMUC). Croatia,

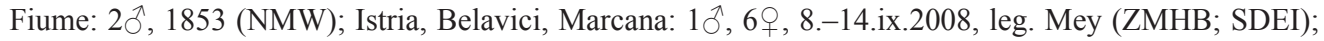
Dalmatia, env. of Selce: 4ð, 8.-15.viii.1989, leg. Gestberger (SDEI). Macedonia, Stari Dojran: 1ㅇ, 2.10.vi.1956, leg. Klimesch (ZSM); Drenovo near Kavadar: 10, 10.-20.vi.1956, leg. Klimesch (ZSM). Albania, Kula Ljums [Kula e Lumes]: $1 \delta^{\Uparrow}$ (NMW); Korab: 1ðึ, 23.-31.vii.1918 (NMW); Gjalica Ljums [Mail i Gjalices]: 2ð̂, 17.-16.vi.1918 (NMW; SDEI); Sisevo near Üsküb: 1ð̂, 11.v.1918 (NMW). Greece, Peloponnese, Zachlorou near Kalavrita: 1ㅇ, 1.-14.vii.1959, leg. Noack (LMAD); Karia: 1 specimen, 12.vii.1974, leg. et coll. Arenberger; Itea/Desfina: 2ð, 29.v.2006, leg. et coll. Schmitz. Bulgaria, Pirin,

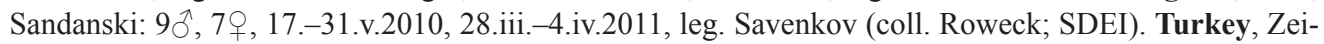
toon: $1 \hat{\jmath}$ (ZMHB); Sivas, darende Günpinar: 1ð̂, 18.x.1986, leg. Moberg \& Hilman (ZMUC); env. of Ürgüp: 1 specimen, 24.vi.1969, leg. et coll. Arenberger; 50km N Tarsus: 1 specimen, 19.v.1969, leg. et coll. Arenberger; Yalova at Sea of Marmara: 1 specimen, 11.v.1969, leg. et coll. Arenberger; Djanik, E of Terme: $1 \hat{\jmath}$, 6.v.1969, leg. Glaser (SMNK); Erzurum: 1ð̂, 17.ix.1993, leg. Fibiger (ZMUC); Agri, $23 \mathrm{~km}$

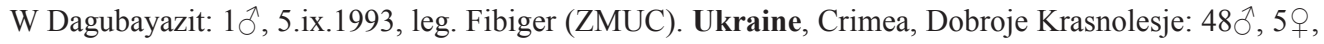
18.v.1983, 5.vii.1986, leg. Zagulajev (ZIN; SDEI); Crimea, Karadag: 10̄, 22.v.1984, leg. Zagulajev (ZIN). Russia, Kaukasus, Kabardino-Balkarski nature reserve, 35km SE of Elbrus: 10 ̊̊, 2 Jalava (FMNH; SDEI). Georgia, Tbilissi: 1ð̄, 30.v.-1.vi.1971, leg. Muche. Armenia, Geghard, 40km E of Erewan: 1ð, 26.-27.vii.1976, leg. Kasy \& Vartian (NMW). Iran, Keredj, Elburs Mountains: 2へ, 1q, 15.iv.1936, leg. Brandt (NHRS); Balochistan, Bendar Tschahabahar: 1ðð, 1937, leg. Brandt (NHRS).

\section{Ochromolopis kaszabi Gaedike, 1973}

Russia, SW-Altai, Kuragan valley, 15km S Katanda, 1200m: 60̂, 23.-25.vii.1983, Exp. K. Mikkola,

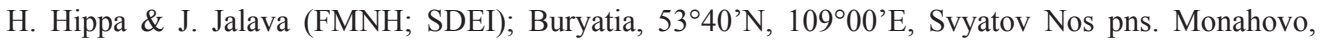

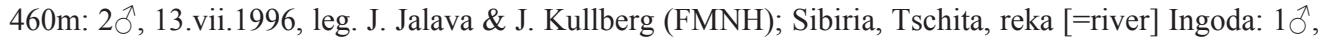
27.vii.1997, leg. I. Kostjuk (ZMHB); Primorskij kraj, Pogranitschnyj Rajon, Barabasch-Levada: 10̄, 5 ㅇ, 14.vii.1989, leg. S. Zinjov (ZIN); Chazanskij Rajon, Kedrovaja pad': 2ô, 2o, 25.vii., 1., 2.viii.1988, leg. S. Zinjov; 1 specimen, 15.vii.1974, leg. Ermolajev (ZIN); Chazanskij Rajon, Rezanovka: 2ð, 2 , 22., 23.viii.1982, leg. S. Zinjov (ZIN); Chazanskij Rajon, 3km SE Andrejevka: 5ô, 5ㅇ, 21., 24.vii., 7., 11., 15.viii.1985, 12,viii.1984, leg. S. Zinjov (ZIN); Chazanskij Rajon, 7km N Zanadvorovka: 5 14.viii.1984, leg. S. Zinjov (ZIN); Ussurijskij Rajon: 2̧, 4ๆ, 3., 12., 19.vii., 14., 19.viii.1982, leg. S. Zinjov (ZIN); Ussurijskij Rajon, surround of Ussurijsk: 3今̄, 6우 28.vi., 7., 8., 28.vii., 3.ix.1983, leg. S. Zinjov (ZIN); Ussurijskij Rajon, 20km E of Ussurijsk: 5ð̂, 4, 20.viii.1980, 22.viii.1981, 9.vii.1984, 3., 13.vii.1985, leg. S. Zinjov (ZIN). Mongolia, Bulgan aimak, 7km NW of Somon, Chanzar-galant, 1350m: 16ð̊, 22.vii.1968, leg. Z. Kaszab (HNHM; SDEI). 